\title{
니켈감량 $\mathrm{Fe}-22 \mathrm{Cr}-9.5 \mathrm{Mn}-3.3 \mathrm{Ni}$ 오스테나이트강 주조재의 고온 변형성
}

\author{
안상연·송재숙·홍순익* \\ 충남대학교 신소재공학과

\section{Hot Deformation Behavior of As-cast Low Nickel Fe-22Cr-9.5Mn-3.3Ni Austenite Steel} \\ Sang Yeon Ahn, Jae Sook Song, and Sun Ig Hong* \\ Department of Nanomaterials Engineering, Chungnam National University, Daejeon 34134, Republic of Korea
}

\begin{abstract}
The hot deformation behavior of as-cast and homogenized $\mathrm{Fe}-22 \mathrm{Cr}-9.5 \mathrm{Mn}-3.3 \mathrm{Ni}$ stainless steel was investigated over a temperature range between $600 \sim 1,250{ }^{\circ} \mathrm{C}$. The deformability of the as-cast $\mathrm{Fe}-22 \mathrm{Cr}-9.5 \mathrm{Mn}-3.3 \mathrm{Ni}$ steel decreased with increasing temperature up to $850{ }^{\circ} \mathrm{C}$, and then increased at temperatures between 900 and $1200{ }^{\circ} \mathrm{C}$ caused by dynamic recrystallization at high temperatures above $900{ }^{\circ} \mathrm{C}$. At temperatures between 800 and $900{ }^{\circ} \mathrm{C}$, the discontinuous precipitation of $\mathrm{Cr}_{2} \mathrm{~N}$ and an decrease in ductility were observed in the as-cast steel. The ductility minimum at $850{ }^{\circ} \mathrm{C}$ in the as-cast $\mathrm{Fe}-22 \mathrm{Cr}-9.5 \mathrm{Mn}-3.3 \mathrm{Ni}$ could be associated with cracking at the interface of the lamellar chromium nitrides. The presence of fatal cracking at $1,250{ }^{\circ} \mathrm{C}$ and the loss of hot ductility can be attributed to the partial melting at austenite grain boundaries at high temperatures.
\end{abstract}

(Received November 10, 2016; Accepted January 31, 2017)

Keywords: high temperature strength, elongation, casting, austenite stainless steel, dynamic recrystallization

\section{1. 서 론}

스테인리스강의 주요 이슈 중의 하나는 스테인리스강의 주요 합금원소인 니켈을 불안정한 공급 및 경제성 때문에 다 른 합금원소로 대체하는 기술에 관한 것으로 산업계를 중심 으로 많은 연구가 계속 수행되고 있다. 특히 오스테나이트 안 정화 합금원소인 니켈 대신에 망간과 질소가 다량 첨가된 새 로운 스테인리스강의 제조 및 가공, 기계적 특성, 합금설계 방안에 대한 광범위한 연구가 활발히 진행되고 있다 [1-6]. 또한 유럽을 중심으로 인체 알르레기를 유발하는 금속의 사 용을 제한하는 법규화 움직임 등으로 생체재료, 의료용 도구 나 기기, 그리고 주방용품 등도 니켈을 포함하지 않거나 적은 량 포함되는 스테인리스강으로 대체하려는 수요가 기대되 며, 특히 의학분야에서 이러한 니켈감량 스테인리스강 적용 연구도 활발히 수행되고 있다 [3-6]. 질소는 부식 및 응력부 식균열 저항성을 향상시키며, 오스테나이트을 안정화 시키
는 원소이므로 $[7,8]$ 질소 첨가는 니켈 첨가원소의 비용을 절 감시키는 효율적인 방안이다 [9-12].

크롬과 탄소가 첨가된 니켈감량 오스테나이트 스테인리스 강은 질소와 망간첨가로 오스테나이트을 안정화시킬 수 있 으며, 크롬탄화물 석출로 고온 기계적 특성과 탁월한 내부식 특성을 지녀 엔진 밸브에 널리 사용되고 있다. 자동차 산업에 서 니켈감량 오스테나이트 스테인리스강의 수요는 꾸준히 증가하고 있으나 합금원소의 불완전한 확산과 질소 고용도 차이에 의한 낮은 인성은 열간 가공성과 피로특성에 해로운 영향을 미친다. 열처리와 열가공 공정 동안에 상변태와 열가 공 공정에 따른 자료 부족 및 열간가공성 저하에 따른 수율 감소 등은 가격상승요인으로 작용하여 고온용 니켈감량 오 스테나이트 스테인리스강의 광범위한 사용이 제한되고 있다 [13-16]. 본 연구에서는 고온에서 니켈감량 오스테나이트 스 테인리스강의 고온 기계적 특성 및 미세구조를 관찰하고 연 성 향상을 통한 성형성 증진방법에 대하여 연구하였다.

* Corresponding Author: Sun Ig Hong

[Tel: +82-42-821-6595, E-mail: sihong@cnu.ac.kr]

Copyright (c) The Korean Institute of Metals and Materials 
Table 1. The chemical composition of stainless steel used in the present study $(\mathrm{wt} \%)$

\begin{tabular}{ccccccccc}
\hline composition & $\mathrm{C}$ & $\mathrm{Si}$ & $\mathrm{Mn}$ & $\mathrm{P}$ & $\mathrm{S}$ & $\mathrm{Ni}$ & $\mathrm{Cr}$ & $\mathrm{N}$ \\
\hline & 0.55 & 0.16 & 9.50 & 0.025 & 0.0015 & 3.30 & 21.5 & 0.42 \\
\hline
\end{tabular}
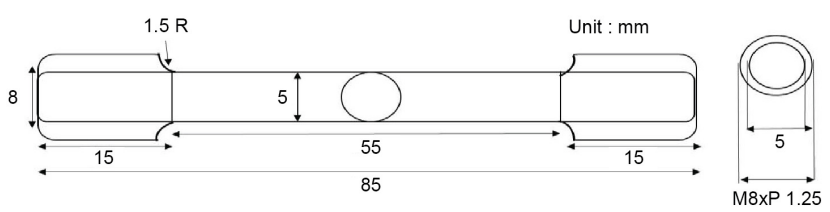

Fig. 1. Schematic illustration of tensile specimen.

\section{2. 실험 방법}

니켈감량 스테인리스강의 고온 기계적 특성에 관한 연구 를 하기 위해 $\mathrm{Ni}$ 의 함량을 낮추고 $\mathrm{Mn}$ 과 질소를 첨가한 $\mathrm{Ni}$ 감 량 오스테나이트 스테인리스강을 용해공정을 이용하여 $\mathrm{A}$ 사 에서 $0.5 \mathrm{~m} \times 0.5 \mathrm{~m} \times 2.5 \mathrm{~m}$ 크기로 주조된 잉고트를 사용하 였다. 질소첨가는 합금용탕에 질소를 주입시켜 행하였으며, 화학조성은 표 1 에 나타내었다. 주조된 시편의 고온가공성을 평가하기 위해 인장시편을 주조한 잉고트 상태에서 또는 균 질화 처리한 주조 잉고트에서 만들었다. 인장시편은 주조 ingot의 표면에서 $5 \mathrm{~cm}$ 내부에 위치한 주상형 조직이 발달한 부위에서 가공하였다. 성형성 개선을 위한 열처리에 따른 기 계적 특성을 평가하기 위하여 인장시험기를 이용하여 인장 실험을 하였으며, 열처리 전/후의 미세조직 분석은 광학현미 경과 $\mathrm{SEM}(\mathrm{JEOL} \mathrm{JSM-5410))을} \mathrm{이용하였다.} \mathrm{인장시편은} \mathrm{직}$ 경 $5 \mathrm{~mm}$, 게이지 길이 $55 \mathrm{~mm}$ 의 크기로 가공하였으며, 그림 1 에 나타내었다. 고온인장시험은 Fuji-Denpa (Kogyo, Japan) 가공시험기를 사용하여 $600 \sim 1,250{ }^{\circ} \mathrm{C}$ 온도범위에서 전 시편 을 가열하여 변형속도 $4 \mathrm{~mm} / \mathrm{min}$ 로 수행하였으며, 각각의 온 도조건에서 3 개씩 시험하여 중간값을 나타내는 데이타를 취 하였다. 전술한 바와 같이 $\mathrm{A}$ 사의 확립된 조건에서 주조된 대 형 잉고트에서 채취된 시편이므로, 특성 데이터의 편차는 아 주 작게 관찰되었다. 인장실험 후 파단된 시편의 파단면은 광 학현미경과 SEM(JEOL JSM-5410)을 이용하여 관찰하였다.

\section{3. 결과 및 고찰}

As-cast 주조재의 미세구조와 주조 후 $1,200{ }^{\circ} \mathrm{C}$ 에서 균질 화 처리시간을 7시간과 24시간 적용한 경우 미세조직을 그림 2에 나타내었다. 그림에서 보는 바와 같이 As-cast의 경우 덴
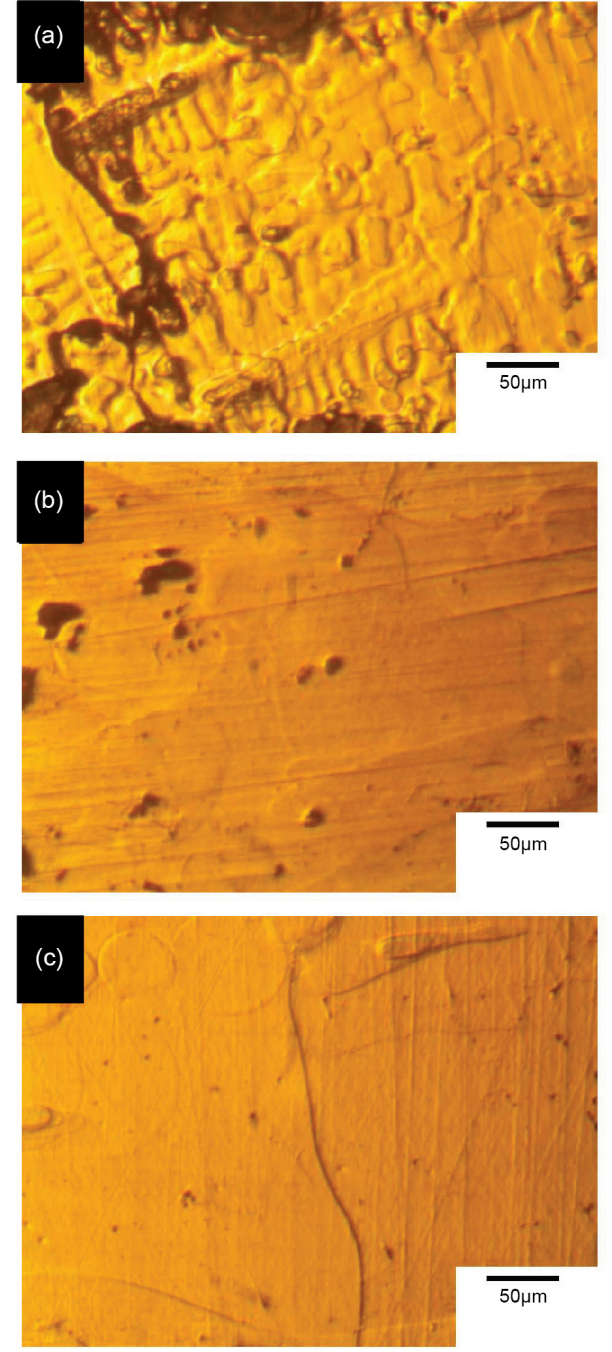

Fig. 2. Microstructure of as-cast and heat treated high nitrogen high manganese austenite stainless steel. a) As-cast, b) $1,200{ }^{\circ} \mathrm{C}$, $7 \mathrm{hr}, \mathrm{c}) 1,200{ }^{\circ} \mathrm{C}, 24 \mathrm{hr}$

드라이트 구조를 나타내며 부분적으로 편석이 존재하는 반 면에 $1,200{ }^{\circ} \mathrm{C}$ 에서 7 시간 균질화처리 한 경우 덴드라이트 구 조가 사라지고 편석도 현저히 감소하였으나, 일부구역에서 불균질상이 발견되었으며, $1,200{ }^{\circ} \mathrm{C}$ 에서 24 시간 열처리한 경 우에는 덴드라이트 구조와 불균일하게 존재하던 편석들이 모두 사라지고 조대한 결정립을 나타내는 미세구조를 보여 준다. 이러한 조대한 결정립은 다른 방향으로 성장한 덴드라 이트 간의 경계 boundary 이며, dendrite 구조가 균질화되어 사라지며 더욱 분명하게 나타나게 된다.

$600 \sim 1,250{ }^{\circ} \mathrm{C}$ 범위의 온도에서 변형속도 $4 \mathrm{~mm} / \mathrm{min}$ 로 인 장시험한 니켈감량 오스테나이트 스테인리스강의 StressStrain Curve를 그림 3에 나타내었다. 그림에서 보여주는 바 


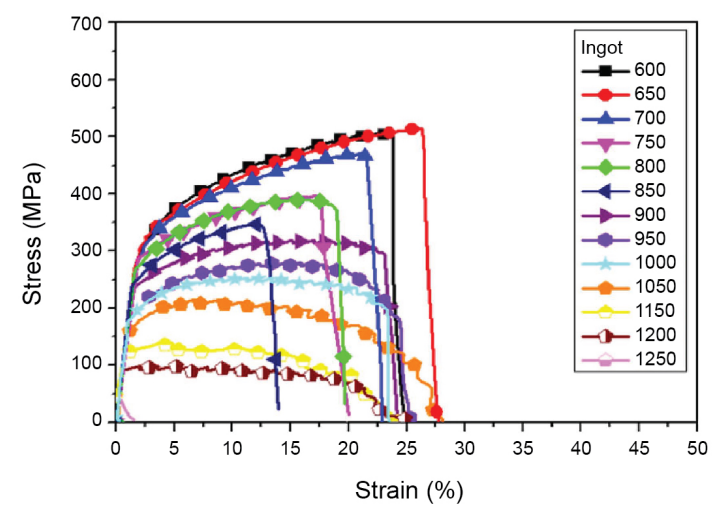

Fig. 3. Stress-strain responses of as-cast high nitrogen high manganese austenite stainless steel.

와 같이 As-cast 니켈감량 오스테나이트 스테인리스강의 강 도는 $600{ }^{\circ} \mathrm{C}$ 에서 $514 \mathrm{MPa}$ 을 나타내며, $1,250{ }^{\circ} \mathrm{C}$ 에서 $35 \mathrm{MPa}$ 로 온도가 증가함에 따라 감소한다. $600{ }^{\circ} \mathrm{C}$ 에서 $900{ }^{\circ} \mathrm{C}$ 까지 는 파단이 발생할 때까지 가공경화 효과를 보이며, $950{ }^{\circ} \mathrm{C}$ 이 상에서는 가공경화 효과가 감소하며 가공연화 효과가 증가 하는 것으로 나타났다. 일반적으로 유동응력(Flow stress)은 초기 가공경화영역에서 증가하고 가공연화영역에서 감소하 기 직전에 최대값에 도달한다 [20-23]. $1,000{ }^{\circ} \mathrm{C}$ 이하의 가공 경화 온도에서 가공경화 속도는 전위의 발생, 소멸, 축적 사 이의 경쟁에 의하여 영향을 받는다 [24-26]. $1000{ }^{\circ} \mathrm{C}$ 이상에 서 연성 증가는 동적재결정에 기인한 가공연화 효과와 연관 되어 있다.

그림 4는 니켈감량 오스테나이트 스테인리스강의 강도와 연성을 온도 증가에 따라 나타내었으며, 그림 4(a)에 강도 변 화를 그림 4(b)에 연성 변화를 나타내었다. 그림 4(a)에서 보 여주는 바와 같이 온도증가에 따라 항복강도와 인장강도가 급격히 감소한다. 흥미로운 현상은 $950{ }^{\circ} \mathrm{C}$ 이하의 온도에서 는 항복강도와 인장강도 차이가 비교적 크나, 온도증가에 따 라 차이는 감소하며, 특히 $1,000{ }^{\circ} \mathrm{C}$ 이상에서는 온도가 증가 함에 따라 항복강도와 인장강도의 차이가 급격히 감소한다. 이와 같은 현상은 온도가 증가함에 따라 가공연화 효과가 커 지게 되기 때문이다. 즉 $950{ }^{\circ} \mathrm{C}$ 이상부터 변형조건이 변화하 기 때문에 Flow stress strain curve의 형상도 온도가 증가함에 따라 가공연화 효과의 기여가 커지며 strain softening 현상이 두드러진다. 그림 4(b)에서 관찰되는 흥미로운 점은 $850{ }^{\circ} \mathrm{C}$ 에서 최소 연성이 나타나며, $900{ }^{\circ} \mathrm{C} \sim 1,200{ }^{\circ} \mathrm{C}$ 에서 연성이 증 가한 후 일정하게 유지된다. $850{ }^{\circ} \mathrm{C}$ 에서 가공경화거동은 변 형율 $12 \%$ 까지 나타나며, 이후 급격한 파단이 발생한다. 900 ${ }^{\circ} \mathrm{C}$ 부터 $1,200{ }^{\circ} \mathrm{C}$ 까지 연성은 $22 \sim 25 \%$ 값을 유지하며, 1,200
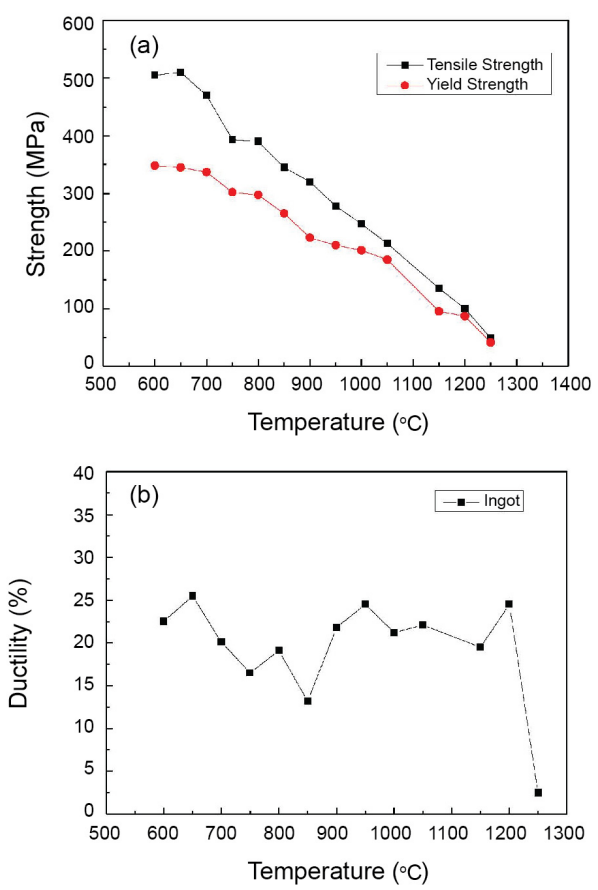

Fig. 4. Strength (a) and ductility (b) of high nitrogen high manganese austenite stainless steel plotted as a function of temperature.

${ }^{\circ} \mathrm{C}$ 에서 최대 연성을 보인다, $1,250{ }^{\circ} \mathrm{C}$ 에서 연성은 급격히 감 소하여 $2 \%$ 연성을 나타내며, 연성감소와 더불어 강도도 급 격히 낮아진다.

니켈감량 오스테나이트 스테인리스강은 높은 강도와 낮은 성형성 때문에 산업계에서 $900 \sim 1250{ }^{\circ} \mathrm{C}$ 에서 가공을 하기 때 문에 균질화 열처리 효과를 관찰하기 위하여 $900 \sim 1250{ }^{\circ} \mathrm{C}$ 에 서 집중적으로 인장실험하여 그림 5에 나타내었다. 그림 5(a) 에 니켈감량 오스테나이트 스테인리스강을 $1200{ }^{\circ} \mathrm{C}$ 에서 7시 간과 24 시간 열처리 한 후 $900 \sim 1,250{ }^{\circ} \mathrm{C}$ 범위에서 인장시험 한 후 강도와 연성 변화를 온도 증가에 따라 나타내었다. 그 림 5(a)에서 보여주는 바와 같이 균질화 처리를 하지 않은 시 편의 인장강도가 $1,200{ }^{\circ} \mathrm{C}$ 에서 균질화 처리를 행한 시편 보 다 모든 시험 온도 범위에서 높게 측정되었다. 이는 주조 시 의 dendrite 형성 및 dendrite arm 사이의 합금원소의 편석이 주조재의 강도를 증진시키며, 조직이 균질화되면 강도가 일 부 감소하게 된다. $1,200{ }^{\circ} \mathrm{C}$ 에서 7시간과 24시간의 균질화 열 처리 시간을 적용한 경우 유사한 강도를 나타내며 온도가 낮 아질수록 as-cast 상태보다 강도의 차이가 증가하고 있다. $1,150{ }^{\circ} \mathrm{C}$ 이상에서 유사한 강도는 고온의 실험온도에서 내부 주조조직의 균질화가 일부 일어나 실험 전 균질화 효과가 크 게 기여하지 못하는 것을 의미한다. 

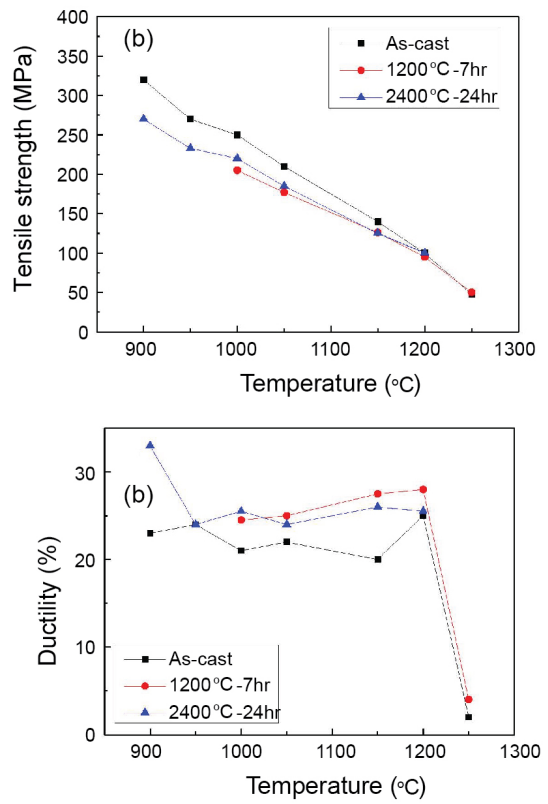

Fig. 5. Tensile strength (a) and ductility (b) of high nitrogen high manganese austenite stainless steel plotted as a function of temperature.

그림 5(b)는 $1200{ }^{\circ} \mathrm{C}$ 에서 7시간과 24시간 열처리 한 후 $900 \sim 1,250{ }^{\circ} \mathrm{C}$ 범위에서 인장시험한 후 연성 변화를 온도 증 가에 따라 나타내었다. 그림에서 보여주는 바와 같이 1,200 ${ }^{\circ} \mathrm{C}$ 에서 균질화 처리를 하지 않은 시편의 연성은 균질화 처리 를 행한 시편 보다 $1,000{ }^{\circ} \mathrm{C}$ 이하에서 낮게 측정되었다. 이는 주조조직의 dendrite 형성 및 합금원소 불균질성과 관련있으 며, 변형이 dendrite때문에 균질하게 일어나지 못해 국부적으 로 변형이 집중된 구역에서 파괴가 일어나기 때문에 연성이 감소하며, 균질화처리된 경우에는 연성이 증가한다. 인장실 험 온도가 $1000{ }^{\circ} \mathrm{C}$ 이상인 경우에도 $1,200{ }^{\circ} \mathrm{C}$ 에서 균질화 처 리시간을 7 시간 또는 24 시간 적용한 시편의 경우 as-cast 시 편보다 연성이 증가하는 것으로 관찰되었다. 마찬가지로 주 조조직이 균질화되어 강도는 감소하지만 연성이 증가하는 조대한 결정립 구조가 형성되기 때문이다.

$1,000{ }^{\circ} \mathrm{C}$ 이상에서도 균질화처리의 영향은 연성을 증가시 키는 것으로 관찰되었다. $1200{ }^{\circ} \mathrm{C}$ 에서 7시간과 24시간 열처 리 한 후 $1000 \sim 1,250{ }^{\circ} \mathrm{C}$ 범위에서 인장시험한 후 연성 변화 를 관찰한 결과, 그림 $5(\mathrm{~b})$ 에서 보여주는 바와 같이 $1,200{ }^{\circ} \mathrm{C}$ 에서 균질화 처리를 한 시편의 연성은 균질화 처리를 행하지 않은 시편 보다 고온구역 $\left(1000 ~ 1,250{ }^{\circ} \mathrm{C}\right)$ 에서도 증가하였 다. 흥미로운 것은 $1,200{ }^{\circ} \mathrm{C}$ 에서 균질화 처리시간을 7 시간 적 용한 시편의 경우가 24 시간 적용한 시편의 경우보다 작기는
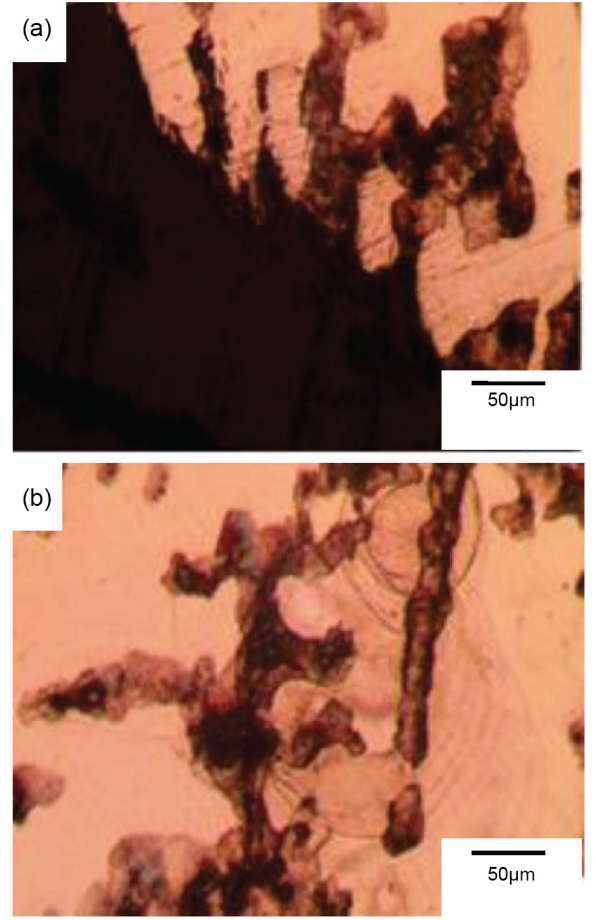

Fig. 6. Longitudinal cross sectional view of cast high nitrogen high manganese austenite stainless steel specimen deformed until fracture at $850{ }^{\circ} \mathrm{C}$. a) near-fracture surface region, b) away from the fracture surface

하지만 $1,050{ }^{\circ} \mathrm{C}$ 이상에서 $2 \%$ 이상 증가하는 것으로 관찰되 었다. 이러한 결과는 일관되게 관찰되었고, 고온에서 성형성 을 조금이라도 증진시키려는 본 연구의 목적으로 볼 때 의미 있는 결과이며 인장시험 후 조직사진과 비교하여 설명하고 자 한다. $1,200{ }^{\circ} \mathrm{C}$ 에서 균질화 처리 후와 고온 인장시험 후의 표면 미세조직 관찰 결과, 니켈감량 오스테나이트 스테인리 스강의 고온가공시 균질화 처리 시간이 동적재결정 정도에 영향을 미치는 것으로 관찰되었다. 주조재의 균질화처리의 영향은 열처리에 따른 주조조직의 균질화 정도에 따른 가공 시의 재결정에 필요한 변형에너지 축적의 용이성 그리고 재 결정립의 성장 용이성에 의해 결정된다.

그림 6는 as-cast 된 시편을 $850{ }^{\circ} \mathrm{C}$ 에서 인장시험한 후 인 장방향에 평행한 파단면의 미세조직을 보여주며, 파단면 부 위를 그림 6(a)에, 파단면에서 $300 \mu \mathrm{m}$ 떨어진 부위의 미세조 직을 그림 6(b)에 나타내었으며, 그림에서 보는 바와 같이 파 면근처나 파면에서 멀리 떨어진 부분 모두 lamellar 형태의 층상조직을 보여주고 있다. 이런 층상 조직은 고온에서 열처 리하는 경우에 형성되며 질소의 분포변화로 층상의 $\mathrm{Cr}_{2} \mathrm{~N}$ 석 출상이 형성되는 것으로 알려져 있다 [27-28]. 


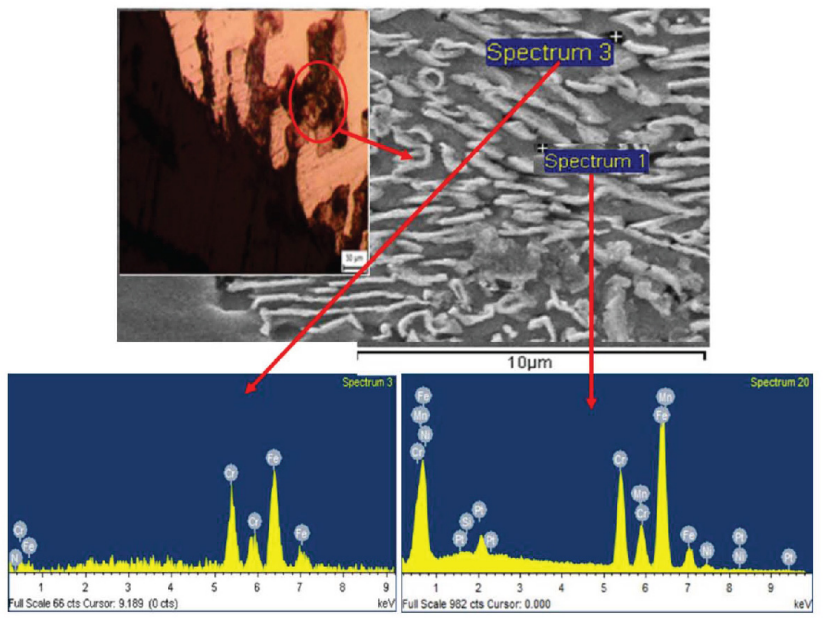

(a) Precipitate

(b) Matrix

Fig. 7. EDS spectra from longitudinal cross section of cast high nitrogen high manganese austenite stainless steel specimen deformed until fracture at $850{ }^{\circ} \mathrm{C}$.

그림 7은 as-cast 된 시편을 $850{ }^{\circ} \mathrm{C}$ 에서 인장시험한 후 인장 방향에 평행한 파단면의 미세조직에서 EDS spectra을 보여준 다. Pt 코팅 후 EDS 분석 결과 lamellar 형상으로 분포하고 있 는 곳에서 흰색의 층에서 그림 7(a)에서 보이는 바와 같이 $\mathrm{Cr}$, $\mathrm{Fe}$, 질소가 검출되어 lamellar 형상은 $\mathrm{Cr}$ 자리에 $\mathrm{Fe}$ 가 일부 치 환된 $(\mathrm{Cr}, \mathrm{Fe}) 2 \mathrm{~N}$ 석출물로 판단된다. 검은 층에서의 $\mathrm{EDS}$ spectra에서는 그림 7(b)에서와 같이 $\mathrm{Fe}, \mathrm{Cr}, \mathrm{Ni}, \mathrm{Mn}$ 과 같이 주 요 치환형 합금원소 성분이 관찰되었다. $\mathrm{Cr}_{2} \mathrm{~N}$ (또는 $(\mathrm{Cr}, \mathrm{Fe}) 2 \mathrm{~N})$ 은 불연속 석출물로 lamellar 형상 때문에 $\mathrm{Cr}_{2} \mathrm{~N}$ pearlite로 불리나 austenite에서 ferrite와 cementite로 분리되 어 형성되는 pearlite 공석반응 과는 달리 계면에서 합금원소 농도가 불연속적으로 급격히 변화하여 austenite조직에서 $\mathrm{Cr}_{2} \mathrm{~N}$ 이 층상으로 형성된 조직이다. $\mathrm{Cr}_{2} \mathrm{~N}$ 석출물은 취성을 나 타내는 물질로 알려져 있으며 [27,28], 일부 2차 크랙은 $\mathrm{Cr}_{2} \mathrm{~N}$ 영역을 따라 성장하는 것으로 관찰되었다. 열처리 한 경우 dendrite 조직에 편석된 $\mathrm{Cr}$ 과 질소의 재용해, 재분배 및 균질화 로 더 고온에서 형성하여 저온에서 연성이 악화되지 않았다.

고질소 오스테나이트 스테인리스강의 경우 고용된 질소가 $850 \sim 1,000{ }^{\circ} \mathrm{C}$ 범위에서 열적으로 불안정하고 고온에서 유지 되는 동안에 질화 석출물 $\left(\mathrm{Cr}_{2} \mathrm{~N}\right)$ 로 형성된다. 그림 $6(\mathrm{a})$ 에서 보여주는 바와 같이 $850{ }^{\circ} \mathrm{C}$ 에서 니켈감량 오스테나이트 스 테인리스강의 파괴는 $\mathrm{Cr}_{2} \mathrm{~N}$ 석출물 영역에서 발생하는 것으 로 판단된다. Simmons와 그 연구진[27]은 $\mathrm{Fe}-19 \mathrm{Cr}-5 \mathrm{Mn}-$ $5 \mathrm{Ni}-3 \mathrm{Mo}-0.02 \mathrm{C}-0.7 \mathrm{~N}$ 강에서 $\mathrm{Cr} 2 \mathrm{~N}$ 석출현상에 의하여 연성 은 감소되며, $900{ }^{\circ} \mathrm{C}$ 열처리 시 석출속도 증가로 연성에 해로
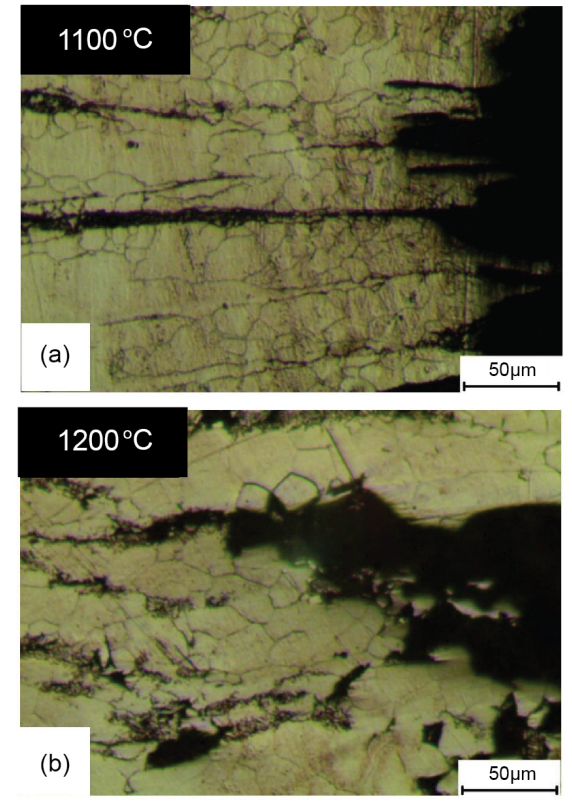

Fig. 8. Longitudinal cross sectional view of cast high nitrogen high manganese austenite stainless steel deformed until fracture at $1,100{ }^{\circ} \mathrm{C}$ (a) and $1,200{ }^{\circ} \mathrm{C}$ (b)

운 영향을 미친다고 보고하였다. 본 연구에서는 최소 연성이 $850{ }^{\circ} \mathrm{C}$ 에서 관찰되었으며, Simmons와 그 연구진[27]에 의한 결과보다는 낮은 온도이다. 즉 낮은 온도에서 $\mathrm{Cr}_{2} \mathrm{~N}$ 석출물의 형성에 의한 연성 감소는 고질소와 고망간 합금원소 첨가에 따라 합금의 용해온도가 낮아지며, 이에 따른 높은 확산도에 기인한다.

그림 8 은 니켈감량 오스테나이트 스테인리스강을 1,100 ${ }^{\circ} \mathrm{C}$ 와 $1,200{ }^{\circ} \mathrm{C}$ 에서 인장시험한 후 인장방향에 평행한 면의 미세조직을 보여주며, 그림 $8(\mathrm{a})$ 에 $1,100{ }^{\circ} \mathrm{C}$, 그림 $8(\mathrm{~b})$ 에 $1,200{ }^{\circ} \mathrm{C}$ 에서의 파단면 근처에 근접한 부위의 미세조직을 나 타낸다. 그림에서 보는 바와 같이 파단면 근처의 높은 변형영 역에서 등축 또는 약간 늘어난 결정립들이 관찰된다. 이는 As-cast 시편의 주조조직이 $1100 ~ 1200{ }^{\circ} \mathrm{C}$ 에서 동적재결정이 일어나 등축형의 결정립으로 변화되었음을 보여준다. 1000 ${ }^{\circ} \mathrm{C}$ 이상의 고온에서 인장실험 시에 인장실험 중에 축적된 에 너지에 의해 동적재결정이 나타나며, 이에 의하여 연성증가 및 성형성 향상이 나타난다. 그림에서 판단면에 수직하게 길 게 늘어진 검은 선들은 국부적으로 불균질 부분에 변형이 축 적되어 작은 모양의 재결정된 결정립들이 길게 늘어져 분포 하기 때문에 나타난다.

그림 8에서 온도가 증가함에 따라 동적재결정 현상이 증가 하였으며, 이는 온도가 증가함에 따라 축적된 변형에너지를 

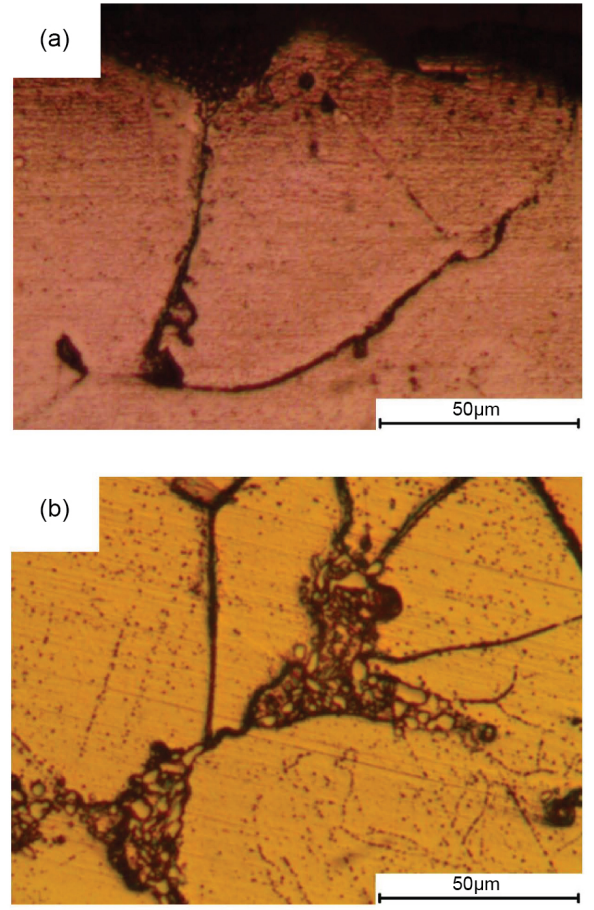

Fig. 9. Longitudinal cross sectional view of cast high nitrogen high manganese austenite stainless steel specimen fractured at $1,250{ }^{\circ} \mathrm{C}$. (a) cracks along the grain boundaries, (b) partially melted and re-solidified grain boundries

완화시키기 위한 동적재결정을 위한 활성화에너지 공급이 쉬워지기 때문이다. 그림 8 에 나타난 바와 같이 $1200{ }^{\circ} \mathrm{C}$ 에서 는 동적재결정 후 결정립(평균 $26 \mu \mathrm{m})$ 이 성장하여 결정립 크 기가 $1100{ }^{\circ} \mathrm{C}$ 결정립(평균 $\left.23 \mu \mathrm{m}\right)$ 보다 약간 큼을 알 수 있다. as-cast 시편이 $1,000 ~ 1,200{ }^{\circ} \mathrm{C}$ 에서 성형성이 향상되는 이유 는 이 온도 구역에서 변형 중 동적재결정 현상이 활발하게 일 어나기 때문이다. 결정립 핵성성 공정이 활성화되기 위해서 는 초기 변형에너지 축적이 요구되며, 따라서 이 온도구간에 서 그림 3에 나타난 바와 같이 초기에는 짧은 변형구간에서 strain hardening이 일어나다 곧 이어 동적재결정에 의한 strain softening이 관찰된다. 변형 동안에 불균일한 As-cast 구조에 의한 소성변형 불균일성이 동적재결정에 의하여 제 거되고, 균일한 변형이 일어나 $1,000 ~ 1,200{ }^{\circ} \mathrm{C}$ 에서 연성의 증가를 나타내게 된다.

그림 9는 니켈감량 오스테나이트 스테인리스강을 1,250 ${ }^{\circ} \mathrm{C}$ 에서 인장시험한 후 인장방향에 평행한 면의 파단면 근처 의 미세조직을 보여준다. 그림 9(a)는 결정립을 따라 발생한 크랙을 보여주며, 그림 9(b)에 부분 용해 후 인장시편 파괴 후 냉각 시에 재 응고된 결정립계을 보여준다. 부분 용융을 확인 하기 위해 DSC분석을 하였으며 흡열반응에 의한 DSC curve
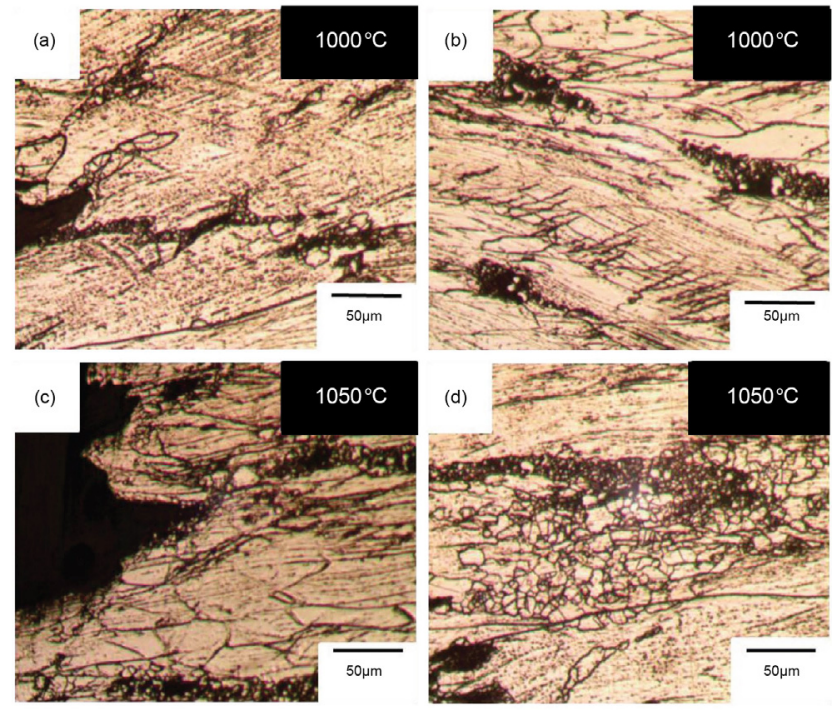

Fig. 10. Longitudinal cross sectional view deformed until fracture of cast high nitrogen high manganese austenite stainless steel specimen heat treated at $1,200{ }^{\circ} \mathrm{C}$ for $7 \mathrm{hr}$. (a, c) near-fracture surface region, $(b, d)$ away from the fracture surface

의 변곡점이 $1220{ }^{\circ} \mathrm{C}$ 부터 시작됨을 관찰하였으며, 이는 부분 용융에 의한 흡열반응으로 해석될 수 있다. 이와 같은 부분 용융에 의한 크랙은 기계적 특성의 불안정성 및 급격한 파괴 의 원인으로 작용하며, $1,250{ }^{\circ} \mathrm{C}$ 에서 관찰되는 강도와 연성 의 급격한 감소로 나타난다. 고온에서 발생하는 크랙과 고온 에서 연성 감소는 다른 오스테나이트계 스테인리스강에서도 관찰되었다 [28].

그림 10 은 니켈감량 오스테나이트 스테인리스강을 1,200 ${ }^{\circ} \mathrm{C}$ 에서 7시간 균질화 처리 한 후 $1,000{ }^{\circ} \mathrm{C}$ 와 $1,050{ }^{\circ} \mathrm{C}$ 에서 인 장시험한 후 인장방향에 평행한 파단면의 미세조직을 보여 주며, 그림 $10(\mathrm{a}, \mathrm{b})$ 에 $1,000{ }^{\circ} \mathrm{C}$, 그림 $10(\mathrm{c}, \mathrm{d})$ 에 $1,050{ }^{\circ} \mathrm{C}$ 에서 인장시험 한 파단면 부근의 미세조직을 나타낸다. 그림에서 결정립 외에 직선으로 보이는 선은 파단면 부위의 변형에 의 해 슬립면, 미소균열, 그리고 변형밴드 등이 에칭 시에 grain boundary와 더불어 축적된 높은 에너지 때문에 같이 에칭되 었기 때문이다. $1,000{ }^{\circ} \mathrm{C}$ 에서 인장시험 한 파단면 부근의 미 세조직을 보면 그림 $10(\mathrm{a}, \mathrm{b})$ 에서 보는 바와 같이 파단면 근처 와 파단면에서 일정 거리 떨어진 부근의 높은 변형영역에서 등축 또는 약간 늘어난 결정립들이 국부적으로 관찰되었다. $1,050{ }^{\circ} \mathrm{C}$ 에서 인장시험 한 미세구조는 그림 $10(\mathrm{c}, \mathrm{d})$ 에서 보 여주는 바와 같이 파단면 근처와 파단면에서 일정 거리 떨어 진 부근의 높은 변형영역에서 광범위하게 동적재결정 결정 립들이 관찰되고 있다. 그림 8(a)의 균질화 열처리하지 않은 

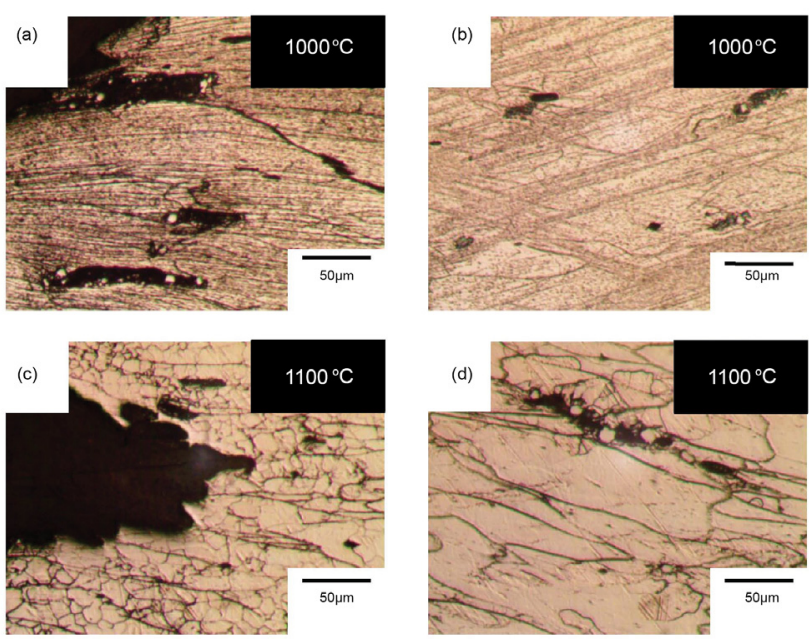

Fig. 11. Longitudinal cross sectional view deformed until fracture of cast high nitrogen high manganese austenite stainless steel specimen heat treated at $1,200{ }^{\circ} \mathrm{C}$ for $24 \mathrm{hr}$. (a, c) near-fracture surface region, $(b, d)$ away from the fracture surface

As-cast 시편의 $1100{ }^{\circ} \mathrm{C}$ 결과와 비교할 때 $1,200{ }^{\circ} \mathrm{C}$ 에서 7시 간 균질화 처리 한 후에 더욱 광범위하게 동적재결정이 일어 남을 보여준다. 이는 그림 $5(\mathrm{~b})$ 에서 $1,200{ }^{\circ} \mathrm{C}$ 에서 7 시간 균질 화 처리 한 후에 연성이 증가하는 결과와 일치한다.

그림 11은 니켈감량 오스테나이트 스테인리스강을 1,200 ${ }^{\circ} \mathrm{C}$ 에서 24 시간 균질화 처리 한 후 $1,000{ }^{\circ} \mathrm{C}$ 와 $1,100{ }^{\circ} \mathrm{C}$ 에서 인장시한 후 인장방향에 평행한 파단면의 미세조직을 보여 주며, 그림 $11(\mathrm{a}, \mathrm{b})$ 에 $1,000{ }^{\circ} \mathrm{C}$, 그림 $11(\mathrm{c}, \mathrm{d})$ 에 $1,100{ }^{\circ} \mathrm{C}$ 에서 인장시험 한 파단면 부근의 미세조직을 나타낸다. $1,000{ }^{\circ} \mathrm{C}$ 에서 인장시험 한 파단면 부근의 미세조직을 보면 그림 11(a, b)에서 보는 바와 같이 파단면 근처와 파단면에서 일정 거리 떨어진 부근의 높은 변형영역에서 인장 방향으로 길게 늘어 난 변형 밴드들이 관찰되며, As-cast 구조후 균질화처리된 조 직이 동적재결정 결정립으로 변화된 결정립들이 국부적으로 관찰된다. $1,100{ }^{\circ} \mathrm{C}$ 에서 인장시험 한 미세구조는 그림 $11(\mathrm{c}$, d)에서 보여주는 바와 같이 파단면 근처와 파단면에서 일정 거리 떨어진 부근의 높은 변형영역에서 광범위하게 동적재 결정 결정립들이 관찰되며, 일부 큰 결정립들도 관찰된다.

$1,200{ }^{\circ} \mathrm{C}$ 에서 균질화 처리를 한 경우, $1,050{ }^{\circ} \mathrm{C}$ 이상에서 동적재결정 현상이 빠르게 증가하였다. $1,000{ }^{\circ} \mathrm{C}$ 에서는 국부 적으로 동적재결정 부위가 관찰되었으며, 그림 $10(\mathrm{a}, \mathrm{b})$ 에서 처럼 파손된후에도 재결정부위가 제한적으로 관찰되는 것으 로 보아, $1000{ }^{\circ} \mathrm{C}$ 에서는 동적재결정이 기계적특성에 미치는 효과가 크지 않은 것으로 보인다. 실제로 그림 3 의 Stress-strain curve에서 $1000{ }^{\circ} \mathrm{C}$ 에서는 strain softening 효과
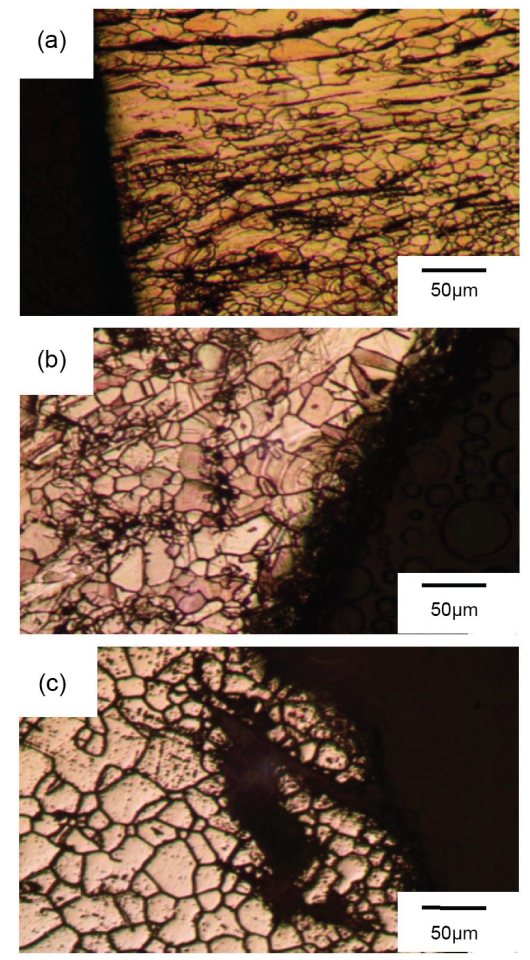

Fig. 12. Longitudinal cross sectional view deformed until fracture of cast and heat treated high nitrogen high manganese austenite stainless steel specimen at $1,150{ }^{\circ} \mathrm{C}$. a) As-cast, b) $1,200,7 \mathrm{hr}, \mathrm{c}$ ) $1,200{ }^{\circ} \mathrm{C}, 24 \mathrm{hr}$

가 뚜렷하지 않으며, $1050{ }^{\circ} \mathrm{C}$ 부터 strain softening 현상이 두 드러지게 관찰되었다. 따라서 $1000{ }^{\circ} \mathrm{C}$ 까지는 균질화에 의한 주조조직 균질화 및 합금원소 균일분포가 연성향상에 큰 영 향을 미친다. $1050{ }^{\circ} \mathrm{C}$ 이상의 극고온 기계적 실험에서는, $1,200{ }^{\circ} \mathrm{C}$ 에서 7 시간 균질화 처리 한 경우 24 시간 균질화 처리 한 조건 보다 상대적으로 변형동안에 불균일한 As-cast 구조 에 의한 소성변형 불균일성이 크기 때문에 동적재결정 현상 이 낮은 온도에서 일어나고, 온도가 증가함에 따라 동적재결 정 현상이 활발하게 일어나기 때문이며, 연성 또한 상대적으 로 높게 관찰된다.

그림 12 은 As-cast와 $1,200{ }^{\circ} \mathrm{C}$ 에서 7시간 및 24시간 균질 화처리한 시편을 $1,150{ }^{\circ} \mathrm{C}$ 에서 인장실험한 미세조직을 보여 준다. 그림에서 보여주는 바와 같이 그림 12(a)는 As-cast, 그 림 12 (b)는 주조 후 $1,200{ }^{\circ} \mathrm{C}$ 에서 7시간 균질화 처리, 그림 11 (c)는 주조 후 $1,200{ }^{\circ} \mathrm{C}$ 에서 24 시간 균질화 처리한 시편의 미세구조를 나타낸다. As-cast 시편을 $1,150{ }^{\circ} \mathrm{C}$ 에서 인장 실 험한 경우, 부분적으로 재결정이 일어나 작은 결정립들과 인 장방향으로 길게 늘어난 변형조직이 공존하는 미세구조를 보이며, $1,200{ }^{\circ} \mathrm{C}$ 에서 7 시간 열처리 후 $1,150{ }^{\circ} \mathrm{C}$ 에서 인장실 


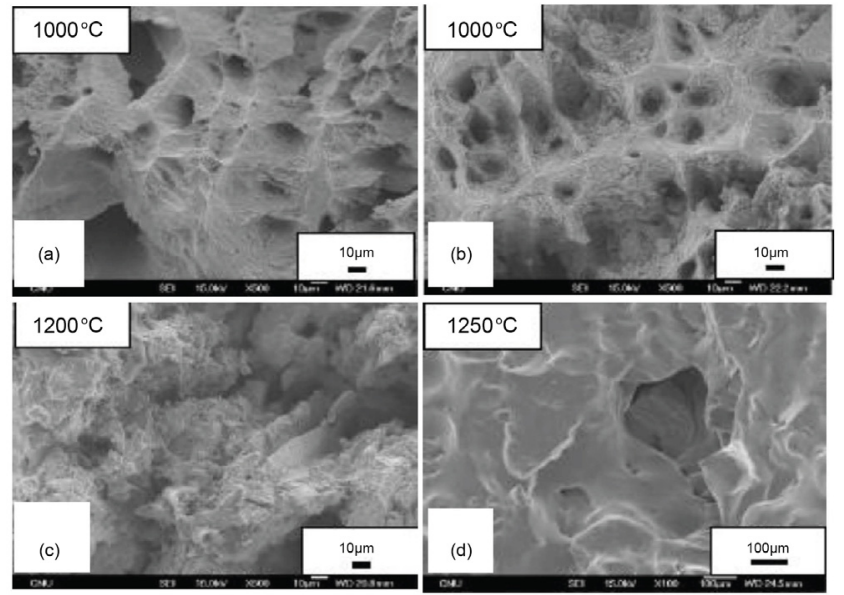

Fig. 13. The fracture surface of the tensile samples at temperature between $1,050{ }^{\circ} \mathrm{C}$ and $1,250{ }^{\circ} \mathrm{C}$.

험한 경우 재결정으로 시편의 넓은 구역에서 동적재결정이 일어났음을 보여주고 있다. $1,200{ }^{\circ} \mathrm{C}$ 에서 24 시간 열처리 후 $1,150{ }^{\circ} \mathrm{C}$ 에서 인장실험한 경우 7 시간 열처리한 경우보다는 조대한 결정립들이 관찰되었다. 고온에서 연성은 변형 중 조 직에 축적된 변형에너지에 의한 동적재결정이 왕성할수록 증가한다. 그림에서 보는 바와 같이 파단 시까지의 지속적인 동적재결정은 $1,200{ }^{\circ} \mathrm{C}$ 에서 7시간 열처리 경우가 가장 활발 함을 알 수 있다.

균질화처리 시간에 따른 연성의 변화는 다음과 같이 설명 할 수 있다. As-cast 조직의 경우 dendrite 조직 및 성분의 불 균질성으로 dendrite boundary가 변형 및 결정립 성장의 방해 물로 작용하여 결정립 성장이 어려워 고온변형에서도 연성 의 증가가 크지 않다. 반면에 $1,200{ }^{\circ} \mathrm{C}$ 에서 7시간 균질화 처 리 한 경우, dendrite 구조의 많은 부위가 용해되어 균질화되 고 일부만 남아(그림 2(b)), 남겨진 일부 방해물에 변형에너 지가 국부적으로 축적되어 동적재결정이 더욱 활발하게 증 가하여 연성이 늘어나는 것으로 판단된다. $1,200{ }^{\circ} \mathrm{C}$ 에서 24 시간 균질화 처리 한 경우에는 dendrite 구조가 완전히 균질 화되어(그림 2(c)), 국부적인 변형에너지의 축적보다는 균일 한 변형이 일어나, 계속적인 변형 중에 동적재결정에 필요한 국부적 임계에너지 달성이 어려워 동적재결정의 지속성이 떨어지는 것으로 판단된다. 따라서 동적재결정을 쉽게 유도 하기 위해서는 방해물이 극도로 많거나, 방해물이 완전히 재 용해된 조직보다는 방해물이 적절히 배치된 구조가 적합하 며, 따라서 $1,200{ }^{\circ} \mathrm{C}$ 에서 7시간 균질화 처리 한 경우가 연성 이 제일 많이 향상된다.

그림 13는 니켈감량 오스테나이트 스테인리스강을
$1,050 \sim 1,250 \quad{ }^{\circ} \mathrm{C}$ 에서 인장실험 후 파단면을 나타낸다. $1,050 \sim 1,150{ }^{\circ} \mathrm{C}$ 에서 파단면은 높은 연성을 갖는 조대한 딤플 파괴가 관찰되며, 온도가 증가함에 따라 동적재결정의 증가 로 딤플파괴 양상은 증가한다. $1,200{ }^{\circ} \mathrm{C}$ 에서 파단면은 취성 파괴가 혼합된 연성파괴 양상을 보인다. $1,250{ }^{\circ} \mathrm{C}$ 에서는 오 스테나이트 결정립계에 부분 용해가 일어나 파단면은 부드 러운 결정립계 형태를 나타내며, 이는 결정립계에서 부분 용 해가 일어났음을 암시한다.

\section{4. 결 론}

$600 \sim 1,250{ }^{\circ} \mathrm{C}$ 에서 As-cast 니켈감량 오스테나이트 스테인 리스강에 대해 고온 기계적 특성과 파괴양상에 대한 연구 결 과 다음과 같은 결론을 얻었다.

1. As-cast 니켈감량 오스테나이트 스테인리스강의 강도는 온도가 증가함에 따라 감소한다. 항복강도와 인장강도의 차 이는 $950{ }^{\circ} \mathrm{C}$ 이하의 온도에서 크게 나타나며, $1,000{ }^{\circ} \mathrm{C}$ 이상 의 온도에서는 온도가 증가함에 따라 차이가 감소하며, 이는 가공연화 현상이 증가하기 때문이다.

2. 최소 연성은 $850{ }^{\circ} \mathrm{C}$ 와 $1,250{ }^{\circ} \mathrm{C}$ 에서 관찰된다. $650{ }^{\circ} \mathrm{C}$ 에 서 $850{ }^{\circ} \mathrm{C}$ 로 온도가 증감함에 따라 연성은 감소하며, $850{ }^{\circ} \mathrm{C}$ 에서 최소 연성을 나타낸다. $850{ }^{\circ} \mathrm{C}$ 에서 $1,200{ }^{\circ} \mathrm{C}$ 까지는 온도 가 증가함에 따라 연성은 증가하나 $1,250{ }^{\circ} \mathrm{C}$ 에서 급격한 연 성감소를 나타낸다.

3. 동적회복은 낮은 온도에서 변형에 중요한 역할을 하며, $1,000 \sim 1,200{ }^{\circ} \mathrm{C}$ 에서는 동적재결정이 큰 영향을 미친다.

4. $1,000 ~ 1,200{ }^{\circ} \mathrm{C}$ 에서 균일한 변형은 이 온도에서 동적재 결정과 연관된다. $1,000 ~ 1,200{ }^{\circ} \mathrm{C}$ 온도에서 As-cast 구조의 불균질한 영역에서 발생하는 불균질 소성변형도 동적재결정 에 의하여 제거되기 때문이다.

5. $1,200{ }^{\circ} \mathrm{C}$ 에서 7시간 균질화 처리 시 $1,000 ~ 1,200{ }^{\circ} \mathrm{C}$ 에서 가장 높은 연성을 나타내며, 이는 $1,200{ }^{\circ} \mathrm{C}$ 에서 7시간 균질화 처리 한 경우, dendrite 구조의 많은 부위가 용해되어 균질화 되고 일부만 남아 남겨진 일부 방해물에 변형에너지가 국부 적으로 축적되어 동적재결정이 더욱 활발하게 증가하여 연 성이 늘어나는 것으로 판단된다.

6. $800 \sim 1,000{ }^{\circ} \mathrm{C}$ 에서 $\mathrm{Cr}_{2} \mathrm{~N}$ 석출물이 생성되며, 연성 감소 를 초래한다. $850{ }^{\circ} \mathrm{C}$ 에서 낮은 연성은 $\mathrm{Cr}_{2} \mathrm{~N}$ 석출물에서 크랙 전파와 연관된다.

7. $1,250{ }^{\circ} \mathrm{C}$ 에서 파괴와 연성 감소는 오스테나이트 결정립 계의 부분 용해에 기인하며, 부분 용해에 따른 일부 결정립계 
의 형태는 파단면에서 관찰된다.

\section{감사의 글}

This research was supported by the Future Material Discovery Program of the National Research Foundation of Korea (NRF) funded by the Ministry of Science, ICT and Future Planning (MSIP) of Korea (2016M3D1A1023532).

\section{REFERENCES}

1. P. J. Uggowitzer, R. Magdowski, and M. O. Speidel, ISIJ Inter. 36, 901 (1996).

2. S. T. Kim, T. H. Lee, C. S. Oh, S. J. Kim, and I. M. Park, J. Kor. Inst. Met. \& Mater. 44, 662 (2006).

3. S. Kim, S. H. Kang, and Y. S. Kim, Korean J. Met. Mater. 54, 154 (2016).

4. D.Kim, Y. Na, S. Seo, and J. Lee, Korean J. Met. Mater. 54, 1659 (2016).

5. V. G. Gavriljuk and H. Bern, Bucher and Tagungsbande, High Nitrogen Steels (1999).

6. H. Bern, ISIJ Int. 36, 909 (1996).

7. G. Stein and I. Hucklenbroich, Mater. Manuf. Process. 19, 7 (2004).

8. M. Sumita, T. Hanawa, and S. H. Teoh, Mater. Sci. Eng. C 24, 753 (2004).

9. H. Hanninen, J. Romu, R. Ilola, J. Tervo, and A. Laitinen, Mater. Process. Technol. 117, 424 (2001).

10. M. O. Speidel, Mat.-wiss. u. Werkstofftech. 37, 875 (2006).

11. P. J. Uggowitzer, R. Magdowski, and M. O. Speidel, ISIJ
Int. 36, 901 (1996).

12. T. D. Ha and M. T. Tsai, J. Adv. Techno. And Eng. Studies. 1, 2, 53 (2015).

13. O. Shchyglo, U. Salman, and A. Finel, Acta. 60, 6784 (2012).

14. J. Menzel, W. Kirschner, and G. Stein, ISIJ Int. 36, 893 (1996).

15. J. Lee, S. Kim, and R. Jeon, J. Adv. Techno. And Eng. Res. 2, 45 (2016).

16. S. Jung, S. S. Sohn, W. M. Choi, B. J. Lee, Y. J. Oh, S. Jang, and S. Lee, Met. Mater. Int. 23, 43 (2017).

17. B. H. Park, H. Y. Um, J. G. Kim, H. Y. Jeong, S. Lee, and H. S. Kim, Met. Mater. Int. 22, 1003 (2016).

18. H.-Y. Ha, T.-H. Lee, and S. Kim, Met. Mater. Int. 23, 115 (2017).

19. R. L. Plau, C. Herrera, D. M. Escriba, P. R. Rios, and A. F. Padilha, Mater. Res. 10, 453 (2007).

20. S. I. Hong and C. Laird, Mater. Sci. Eng. A 128, 55 (1990).

21. S. I. Hong, G. T. Gray, and J. J. Lewandowski, Acta Metal. Mater. 41, 2337 (1993).

22. S. I. Hong, J. S. Song and H. S. Kim, Scr. Mater. 45, 1295 (2001).

23. W. J. Kim, J. P. Kim, W. Y. Choo, S. I. Hong, and J. D. Lee, Mater. Lett. 51, 177 (2001).

24. R. C. Souza, E. S. Silva, A.M. Jorge Jr, J. M. Cabrera, and O. Balancin, Mater. Sci. Eng. A 582, 96 (2013).

25. J. J. Jonas, X. Quelennec, L. Jiang, and E. Martin, Acta Mater. 57, 2748 (2009).

26. S. I. Hong, Mater. Sci. Eng. 79, 1 (1986).

27. J. W. Simmons, B. S. Covino Jr, J. A. Hawk, and J. S. Dunning, ISIJ Int. 36, 846 (1996).

28. E. Erisir, U. Parhl, and W. Bleck, Metall. Mater. Trans. A 44, 5549 (2013). 